Meta

Journal des traducteurs

Translators' Journal

\title{
Israël Pincus Lazarovitch alias Irving Layton
}

\section{Jean Antonin Billard}

Volume 45, numéro 1, avril 2000

La traduction littéraire au Canada

Literary Translation in Canada

URI : https://id.erudit.org/iderudit/002080ar

DOI : https://doi.org/10.7202/002080ar

Aller au sommaire du numéro

Éditeur(s)

Les Presses de l'Université de Montréal

ISSN

0026-0452 (imprimé)

1492-1421 (numérique)

Découvrir la revue

Citer cet article

Billard, J. A. (2000). Israël Pincus Lazarovitch alias Irving Layton. Meta, 45(1), 140-154. https://doi.org/10.7202/002080ar

\section{Résumé de l'article}

Depuis cinq décennies, le poète Irving Layton tente de témoigner de l'indicible et donc de l'intraduisible obscénité de la Shoah. Jamais il ne renoncera à sa quête à l'exemple d'Isaïe, bien qu'il voie avec trop d'évidence qu'impureté et lâcheté font résonner la voix du poète comme une cloche fêlée. Dans le verbe créateur demeure la rédemption. Le Carillon. La traduction française de dix poèmes s'efforce de retrouver dans un autre idiome cette voix, qui était déjà traduite, dans l'original anglais, d'une langue intérieure étrangère, la langue du nom éradiqué. Cette absence du nom, cette "parole suffoquée" met, à son tour, le traducteur au défi. 


\title{
Israël Pincus Lazarovitch alias Irving Layton
}

\author{
JEAN ANTONIN BILLARD \\ Critique et traducteur
}

\section{RÉSUMÉ}

Depuis cinq décennies, le poète Irving Layton tente de témoigner de l'indicible et donc de l'intraduisible obscénité de la Shoah. Jamais il ne renoncera à sa quête à l'exemple d'Isaïe, bien qu'il voie avec trop d'évidence qu'impureté et lâcheté font résonner la voix du poète comme une cloche fêlée. Dans le verbe créateur demeure la rédemption. Le Carillon. La traduction française de dix poèmes s'efforce de retrouver dans un autre idiome cette voix, qui était déjà traduite, dans l'original anglais, d'une langue intérieure étrangère, la langue du nom éradiqué. Cette absence du nom, cette «parole suffoquée» met, à son tour, le traducteur au défi.

\begin{abstract}
For five decades, poet Irving Layton has attempted to bear witness to the unspeakable and untranslatable obscenity of the Shoah. Like Isaiah, he will never give up his quest, although it's all too clear that impurity and cowardice make the poet's voice ring with a cracked sound like that of a broken bell. From the creative word comes redemption. The French translation of ten poems tries to convey in a different idiom this voice, which in English was already a translation of an internal foreign language, the language of the obliterated name. This absence of a name, this "stifled language" is in turn a challenge for the translator.
\end{abstract}

\section{MOTS-CLÉS/KEYWORDS}

Irving Layton, poésie, judaïsme, Holocauste, traduction littéraire

Après Auschwitz, la poésie n'est plus ce chant langoureux et intime que nombre de nos contemporains voudraient encore qu'elle fût. Irving Layton, témoin lucide d'un temps sans pitié, est un poète impitoyable pour un monde sans piété, sans mémoire.

Irving Layton est juif et ne s'en remettra jamais. Vivant, l'homme ne guérira jamais de ses morts. Sans se résigner au silence, il l'appelle en hurlant: il éructe sa rage et crache son espoir à la face des assassins.

Des poètes aussi j'aimerais un discours direct,

pas de pleurnicheries, chaque mot serait un coup.

Dans les déserts sans eau, les cactus s'ouvrent au soleil

et leur parfum est cet autre langage que les buses connaissent ${ }^{1}$.

Depuis cinq décennies, le poète tente de témoigner de l'indicible et donc intraduisible obscénité de la Shoah, mais...

Jamais il ne renoncera à sa quête

à l'exemple d'Isaïe, bien qu'il voie avec trop d'évidence

qu'impureté et lâcheté

font résonner la voix du poète comme une cloche fêlée ${ }^{2}$.

Pourtant: «Dans le verbe créateur demeure la rédemption.» 
Chez Layton, «...tous les pouvoirs de l'homme se sont résumés dans sa langue. C'était pour lui un problème vital que la transformation en orgueil de son altérité immuablement douloureuse ${ }^{3} »$.

La poésie seule est communication d'un incommunicable et «le poète moderne est l'irrécusable témoin ${ }^{4} »$.

Chères familles assassinées

je serai votre langue brûlée et gonflée

pour exprimer les malédictions

que les balles et les gaz ont étouffées sur vos lèvres.

Remplissez, remplissez mes oreilles de vos jurons les plus terribles.

Je leur donnerai voix, sur un ton sans appel,

jusqu'à ce que le soleil devienne noir dans le ciel $^{5}$.

On désespère de jamais pouvoir représenter cette mort ignominieuse. Il y a un avant et un après, mais le trou noir de la chambre à gaz et de l'asphyxie échappe au récit. Ce meurtre de masse pulvérise la catégorie classique de l'histoire entendue comme un récit. Ici il n'y a rien à raconter qu'une fermeture des portes sur un trou noir et leur réouverture un peu après. Entre les deux se situe ce que beaucoup nomment avec le cardinal Jean-Marie Lustiger le «soleil noir de la Shoah ${ }^{6} »$.

Vladimir Jankélévitch : «Et ainsi quelque chose nous incombe. Ces innombrables morts, ces massacres, ces torturés, ces piétinés, ces offensés, sont notre affaire à nous tous. Qui en parlerait si nous n'en parlions pas? [...] Les morts dépendent entièrement de notre fidélité.»

La poésie est un murmure imperceptible une confidence offerte aux morts, à eux dite de mémoire... ${ }^{7}$

Désormais tu es la réalité

Petit homme

à l'aune de laquelle tout doit être mesuré et mis à l'épreuve. N'avez-vous pas remarqué?

Tout le monde vit comme si Auschwitz n'avait jamais été8.

Or...

l'oubli

de l'extermination

fait partie

de l'extermination'.

\section{THE CARILLON}

Like a sponge the poet soaks up the sewage of evil trespass and self-delusion running through the ruts of this dark epoch. His head is a black cloud about to burst.

From his own self must come light and truth, the long-awaited word to stifle discord; 
let it be plain as cut parsnip on a plate or the wall of his house when sunlight strikes.

Utterance alone can heal the ailing spirit and make man and poet a single self; bring back on the long vein of memory the laughter and wholeness of childhood.

Never will he beg off from his pursuit as did Isaiah though he sees too plain how impurity and self-betrayal make the prophet's voice clunk like a cracked bell.

In the creative word lies redemption. At the darkest hour somewhere the sun, the life-giving sun, turns feculent swamps into grasslands where gazelles run and play.

Let it burn out the eyes of his sockets. He'll stare it down into the terrorized cities; bring his human fears to it as to a bonfire and hear his voice chime like a carillon.

(1982 - A Wild Peculiar Joy: Selected Poems 1945-1982, Toronto, McClelland \& Stewart, 1982)

\section{LE CARILLON}

Comme une éponge le poète s'imbibe du cloaque de l'ignoble transgression et de l'aveuglement que charrient les égouts de cette époque sombre. Sa tête est un nuage noir sur le point de crever.

De lui-même doivent naître lumière et vérité le mot tant attendu pour étouffer la discorde; qu'il soit simple comme un panais dans l'assiette ou le mur de sa maison quand le soleil le frappe.

Seule la parole peut guérir l'esprit souffrant et faire du poète et de l'homme une seule personne; ramener par les longues veines de la mémoire le rire et l'innocence de l'enfant.

Jamais il ne renoncera à sa quête à l'exemple d'Isaïe, bien qu'il voie avec trop d'évidence qu'impureté et lâcheté font résonner la voix du poète comme une cloche fêlée.

Dans le verbe créateur demeure la rédemption.

À l'heure la plus noire quelque part le soleil, le soleil de vie, transforme les marais putrides en prairies verdoyantes où folâtrent les gazelles.

Que le soleil brûle ses yeux dans leur orbite. Lui le plongera au cœur des villes terrorisées et y apportera ses peurs d'homme comme à un bûcher pour entendre sa voix sonner comme un carillon. 


\section{AFTER AUSCHWITZ}

Myson,

don't be a waffling poet;

let each word you write

be direct and honest

like the crack of a gun

Believe an aging poet

of the twentieth century;

neither the Old Testament

nor the New

or the sayings of the Koran

or the Three Baskets of Wisdom

or the Dhammapada

will ever modify or restrain

the beastliness of men

\section{Lampshades}

were made from the skins

of a people

preaching the gospel of love;

the ovens of Auschwitz and Belsen

are open testimony

to their folly

Despite memorial plaques

of horror and contrition

repentance, my son,

is short-lived;

an automatic rifle, however,

endures

a lifetime.

(1968 - The Unwavering Eye: Selected

Poems, 1969-1975, 1975)

\section{RHINE BOAT TRIP}

The castles on the Rhine

are all haunted

by the ghosts of Jewish mothers

looking for their ghostly children

And the clusters of grapes

in the sloping vineyards

are myriads of blinded eyes

staring at the blind sun

The tireless Lorelei

can never comb from their hair

the crimson beards

of murdered rabbis

\section{APRÈS AUSCHWITZ}

Mon fils,

ne sois pas un poète bavard

que chaque mot que tu écris

soit direct et honnête

comme un coup de fusil

Crois en un poète vieillissant

du vingtième siècle:

ni l'Ancien Testament

ni le Nouveau

ni les versets du Coran

ou les Trois paniers de la sagesse

ou le Dhammapada

ne changeront ni ne freineront

la bestialité des hommes

Des abat-jour

ont été faits avec les peaux

d'un peuple

qui prêchait l'évangile de l'amour; les fours d'Auschwitz et de Belsen sont de manifestes témoignages de leur folie

En dépit des plaques commémoratives de l'horreur ou de la contrition le repentir, mon fils, est de courte durée; un fusil automatique, toutefois, dure une vie entière

\section{CROISIÈRE SUR LE RHIN}

Les châteaux du Rhin

sont tous hantés

par les ombres des mères juives

à la recherche du spectre de leurs enfants

Et les grappes de raisin

dans les vignes à flanc de côte

sont des myriades d'yeux morts

fixés sur un soleil aveugle

Les inlassables Lorelei

jamais ne parviennent à démêler

leurs blondes crinières des barbes cramoisies de rabbins assassinés 
However sweetly they sing one hears only the low wailing of cattle-cars moving invisibly across the land

(Fall 1966 - The Darkening Fire: Selected Poems 1945-1968, Toronto, McClelland \& Stewart, 1975)

\section{MIDSUMMER DREAM IN THE VIENNA STADPARK}

Auschwitz, as we know, is on the moon And Belsen on Mars or Venus.

How can I not believe it?

The waltz strains are so entrancing

Anne Frank is alive and well And so's sister Margot;

In fact they're right here in the park

Seated beside the gentleman in the third row.

How handsome the two sisters look

- Anne's eyes, as always, are radiant;

They are drinking in the music

And can scarcely keep their feet from dancing.

And they praise the statue of Johann Strauss, a single curve of pure delight;

Time sleeps on his violin

And he smiles at them all through the night.

Someone has gone to find their father;

He should be here any minute now.

Ah, happy man, run fast, faster.

Do not stop to wipe your brow.

For all in the park recognize Anne And stand up as one to applaud her Because though doomed herself she wept When she saw gypsy children led to the gas chamber.

(1974 - A Wild Peculiar Joy: Selected Poems 1945-1982,

Toronto, McClelland \& Stewart, 1982)

\section{SONGE D'UNE NUIT D'ÉTÉ DANS} LE STADPARK DE VIENNE

Auschwitz, comme on sait, est sur la lune

Et Belsen sur Mars ou Vénus.

Comment ne pas le croire?

Les accords de la valse sont tellement ravissants.

Anne Frank est en vie et se porte bien

Tout comme sa sœur Margot;

En fait, elles sont bien ici dans le parc

Assises aux côtés du Monsieur au troisième rang.
Aussi doux soient leurs chants seul s'entend le long gémissement des charettes qui traversent, invisibles, les terrres 
Comme elles sont belles ces deux sœurs

- les yeux d'Anne, comme toujours, sont radieux;

Elles s'abreuvent de musique

Et peuvent à peine retenir leurs pieds de danser.

Et elles font l'éloge de la statue de Johann Strauss, pur délice d'une simple courbe;

Le temps s'est endormi sur son violon

Et lui leur sourit à la nuit longue.

Quelqu'un est allé chercher leur père;

Il devrait être ici d'une minute à l'autre.

Ah, heureux homme, cours vite, plus vite encore.

Ne t'arrête pas pour t'éponger le front.

Car tout le monde dans le parc reconnaît Anne

Et se lève comme un seul homme pour l'applaudir

Parce que bien que condamnée elle-même elle pleura

Quand elle vit qu'on emmenait les enfants gitans vers la chambre à gaz.

\section{THE FINAL SOLUTION}

It's been all cleared away, not a trace:

laughter keeps the ghosts in the cold ovens

and who can hear the whimpering of small children

or of beaten men and women, the hovering echoes,

when the nickelodeons play all day the latest Berliner

love ballads, not too loudly, just right?

Taste the blood in the perfect Rhenish wine

or smell the odour of fear when such lovely

well-scented frauleins are fiddling with the knobs

and smiling at the open-faced soldier in the corner?

History was having one of its fits - so what?

What does one do with a mad dog? One shoots it

finally and returns armless and bemedalled

to wife and children or goes to a Chaplin film

where in the accomodating dark the girlfriend

unzips your fly to warm her hands on your scrotum.

Heroes and villains, goodies and baddies, what

will you have to drink with your goulash? In art museums

together they're shown the mad beast wagging its tail

at a double-hooked nose that dissolves into ash

And appraised by gentlemen with clean fingernails

who admire a well-executed composition or pointed to

in hushed tones so that nothing of the novel frisson

be lost. Europe blew out its brains

for that frisson: gone forever are the poets and actors,

the audacious comics that made Vienna and Warsaw

hold their sides with laughter. Gone, gone forever.

They will never return, these wild extravagant souls:

mediocrity stopped up their witty mouths,

envy salted the ground with their own sweet blood. 
Sealed up their light in the lightless halls of death.

Alas, the world cannot endure too much poetry:

a single cracked syllable - with a cognac - suffices.

I have seen the children of reingemacht Europe, their

queer incurious dead eyes and handsome blank faces,

leather straps and long matted hair their sole madness.

They have no need of wit or extravagance, they have

their knapsacks, their colourful all-purpose knapsack.

The nickelodeon grinds on like fate, six fatties play cards:

the day is too ordinary for ghosts or griefs.

(1974 - Fortunate Exile, Toronto, McClelland \& Stewart, 1982)

\section{LA SOLUTION FINALE}

Tout a été nettoyé, pas une trace:

le rire retient les fantômes dans les fours froids

et qui peut entendre le gémissement des petits enfants

ou des hommes et des femmes battus, les échos qui rôdent,

quand, à longueur de journée, les juke-box jouent les dernières romances

berlinoises, pas trop fort mais juste assez?

Goûter le sang dans l'excellent vin du Rhin

ou sentir l'odeur de la peur quand de si belles

frauleins parfumées jouent avec les boutons du bastringue

et sourient au soldat au visage ouvert dans le coin?

L'histoire avait un de ses accès de folie - et alors?

Que fait-on d'un chien enragé? On finit par le tuer

et on retourne désarmé et décoré

vers sa femme et ses enfants ou on va voir un film de Chaplin

où dans la commode obscurité, la petite amie

ouvre votre braguette pour se réchauffer les mains sur votre scrotum.

Héros et gredins, gentils et méchants, que

boirez-vous avec votre goulash? Dans les musées,

sont exposés ensemble la bête enragée qui agite sa queue

à l'intention d'un nez crochu qui se dissout en cendres

Et évalués par des messieurs aux ongles bien propres

qui admirent une composition bien exécutée ou désignés

du doigt à voix basse pour ne rien perdre du frisson

original. L'Europe a fait sauter ses cervelles

pour ce frisson: à jamais perdus ces poètes, ces acteurs,

ces audacieux comiques qui ont fait Vienne et Varsovie

se tordre de rire. Partis, partis pour toujours.

Elles ne reviendront jamais ces belles âmes extravagantes:

la médiocrité ferma leurs bouches spirituelles,

l'envie sala le sol de leur sang si doux.

Enferma leur lumière dans les couloirs sans lumière de la mort.

Hélas, le monde ne peut endurer trop de poésie:

une seule syllabe lâchée - avec un cognac - suffit.

J'ai vu les enfants de l'Europe reingemacht, leurs

étranges yeux morts indifférents et leurs beaux visages muets,

sangles de cuir et longs cheveux nattés, leur unique folie. 
Ils n'ont nul besoin d'esprit ou d'extravagance, ils ont leurs havresacs, leur havresac pittoresque et pratique.

Le juke-box continue à grincer comme le destin, six gros bonshommes jouent aux cartes: ce jour est trop ordinaire pour les fantômes ou le chagrin.

\section{FOR 7515-03296}

Your eyes are dark and tragic as history as you stare at the postcard village in the distance; you are a distinguished graduate from Auschwitz and mankind's incurable viciousness, and your slender arm with its tattooed figures boldly displays your credentials to the world.

Each time, my dear, I see your naked loveliness on this deserted beach my heart is torn apart by love and loathing, gratitude and disgust, by reverence and rage until my frantic mind scurries like that insect between the hot stones and I grow deaf to all but the waves' savage gulps

And though I know that all the innocent dead find their resurrection in us and every loving pair, imaging the dateless horror of the death camp, the lexicon of human villainy made plain, I curse without ceasing into the sweet empty air and feel my loathing for mankind grow as vast as the sea

(December 1977 - The Tightrope Dancer, Toronto, McClelland \& Stewart, 1978)

\section{POUR LE 7515-03296}

Tes yeux sont noirs et tragiques comme l'histoire alors que tu fixes ce village de carte postale au loin; tu es une diplômée de marque d'Auschwitz et de l'incurable méchanceté humaine, et ton bras amaigri avec ses chiffres tatoués expose impudemment tes titres au monde

Chaque fois, ma chère, que je vois ta beauté nue sur cette plage déserte mon cœur est déchiré par l'amour et la haine, la gratitude et le dégoût, par la vénération et la rage jusqu'à ce que mon esprit affolé détale comme cet insecte entre les pierres chaudes et que je devienne sourd à tout sauf aux coups sauvages des vagues

Et bien que je sache que tous les morts innocents trouvent leur résurrection en nous et chaque couple d'amants, imaginant l'horreur sans date du camp de la mort, le lexique clair et précis de l'humaine vilenie, je lance mes imprécations incessantes dans l'air doux et vide et sens mon dégoût pour l'humanité devenir aussi vaste que la mer 


\section{TO THE VICTIMS OF THE HOLOCAUST}

Your horrible deaths are forgotten;

no one speaks of them anymore.

The novelty of tattooed forearms wore off quickly; people now say your deaths are pure invention, a spoof.

More corrosive of human pride than Copernicus or Darwin, your martyrdoms must lie entombed in silence.

The devil himself is absolved, polyhistors naming him the only fascist in Europe ignorant you were changed into soap and smoke.

That's how the wind blows. Tomorrow some goy will observe you never existed and the Holocaust your just deserts for starting wars and revolutions.

I live among the blind, the deaf, and the dumb. I live among amnesiacs.

My murdered kin let me be your parched and swollen tongue uttering the maledictions bullets and gas silenced on your lips.

Fill, fill my ears with your direst curses. I shall tongue them, unappeasable shades, till the sun turns black in the sky.

(1978 - The Tightrope Dancer, Toronto, McClelland \& Stewart, 1978)

\section{AUX VICTIMES DE L'HOLOCAUSTE}

Vos morts affreuses sont oubliées; personne n'en parle plus.

L'étrangeté des avant-bras tatoués s'est vite dissipée; on dit maintenant que votre mort est pure invention, une blague.

Plus corrosif pour l'orgueil humain que Copernic ou Darwin, votre martyre doit rester enseveli dans le silence.

Le diable lui-même est absent, un tas d'historiens le disant le seul fasciste en Europe passant sous silence que vous avez été transformées en savon et en fumée.

C'est ainsi que le vent souffle. Demain quelque goy fera observer que vous n'avez jamais existé et que l'Holocauste n'est que votre châtiment bien mérité pour les guerres et les révolutions que vous avez fomentées. 
Je vis parmi les aveugles, les sourds et les muets.

Je vis parmi les amnésiques.

Chère famille assassinée

je serai votre langue brûlée et gonflée

pour exprimer les malédictions

que les balles et les gaz ont étouffées sur vos lèvres.

Remplissez, remplissez mes oreilles de vos jurons les plus terribles.

Je leur donnerai voix, sur un ton sans appel,

jusqu'à ce que le soleil devienne noir dans le ciel.

\section{EINE KLEINE NACHTMUSIK}

I was nowhere near

the syphilitic whore called Europe

smelling of charnel houses and museums

And was not there

when you ripped open the bellies

of pregnant women

Nor when you laughed uproariously

at the spectres

clawing one another for offal

I was not there when you made skeletons

dance for you

and grief-crazed Jewesses to sing

If you're dead

you're beyond my curses and contempt

inviolable as a jackal's calcified turd

But alive and still insurable,

you're probably in Obersalzburg

letting Mozart ravish your souls

Or in Budapest, Vilna, Cologne

buying sausages, perhaps

Xmas toys for your grandchildren

Why not? Since power's the world's standard

it's your victims, not you,

who feel besmirched and guilty

$A h$, meine berren, we live in a time

when atrocity's the norm

and survival the sole merit

In 1980 everyone lives

with some gas in his lungs.

No one will die of it.

(Fall 1980 - A Wild Peculiar Joy: Selected Poems

1945-1982, Toronto, McClelland \& Stewart, 1982) 


\section{EINE KLEINE NACHTMUSIK}

J'étais à mille lieues

d'Europe, cette putain syphilitique

aux parfums de charniers et de musées

J'étais à mille lieues, c'est vrai

lorsque vous éventriez

les femmes enceintes

Quand vous vous esclaffiez

au spectacle de ces spectres

se déchirant entre eux pour des déchets

Non je n'étais pas là quand, pour votre plaisir,

vous faisiez danser des squelettes

et chanter ces Juives folles de douleur

Morts si vous êtes,

à mes malédictions et mon mépris vous échappez

inviolables comme l'étron calcifié d'un chacal

Mais vivants et assurables encore,

vous êtes sans doute à Obersalzburg

l'âme ravie à l'écoute de Mozart

Ou bien à Budapest, à Vilnius ou Cologne

achetant des saucisses, ou même

des jouets pour le Noël de vos petits-enfants

Et pourquoi pas? Puisque le pouvoir est la règle du monde ce sont bien vos victimes et non pas vous

qui se sentent coupables et souillées

$\mathrm{Ah}$, meine berren, nous vivons une époque

où l'atrocité fait la norme

et survivre le seul mérite.

En 1980, nous vivons, tous

avec un peu de gaz dans les poumons

mais personne n'en mourra.

\section{REINGEMACHT}

Why are the birds flying overhead?

Do they make out the waves to be rotting heads?

Do they smell black carrion drifting on the sea?

The midday sun is in the sky,

throwing down his small silver horseshoes

that land near the bobbing heads and floating corpses.

The dog that was friendly yesterday

frantically scoops the sand with his forepaws

as if he were thirstily digging for water

and covers my books and papers with it. He never stops.

I notice a mysterious swarm of flies

where the children are building castles and moats.

A small boat chugs past. A water-skier 
alights suddenly as if from nowhere

like an angel come to warn us. Of what?

I fear the worst, brothers and friends.

The calm sea, the blue sky, the laughing children

are deceptions. I tell you I smell burning wood.

I see and hear sizzling flesh, the hissing oils and fats

start fires in the streets.

Tall building sway and totter like old men

before they crumble into a waterfall of bricks.

The cries and moans never cease.

The cities of the plain are burning.

London. Berlin. Vienna. Warsaw. Moscow.

Night after night, they blaze like enormous faggots

against the lowering sky.

A hideous smell of gas covers Europe from end to end.

When the cities have burned themselves out

the heavens will open up

and black torrential rains will descend for forty days

and forty nights.

Everything alive is submerged and drowned.

I see no tossing ark.

(1980 - A Wild Peculiar Joy: Selected Poems 1945-1982,

Toronto, McClelland \& Stewart, 1982)

\section{REINGEMACHT}

Pourquoi les oiseaux volent-ils dans le ciel?

Donnent-ils aux vagues cette apparence de têtes en décomposition?

Ont-ils cette odeur de charogne noire qui dérive sur la mer?

Le soleil de midi dans le ciel

lance ses petits fers à cheval argentés

qui tombent à côté des têtes qui dansent et des cadavres qui flottent.

Le chien qui était gentil hier

creuse furieusement le sable avec ses pattes de devant

comme si, assoiffé, il creusait pour trouver de l'eau

et en recouvre mes livres et mes papiers. Sans s'arrêter.

J'aperçois une mystérieuse nuée de mouches

là où les enfants construisent des châteaux et des douves.

Un petit bateau passe en haletant. Un skieur nautique

atterrit soudain comme s'il venait de nulle part

comme un ange pour nous prévenir d'un danger. De quel danger?

Je crains le pire, frères et amis.

La mer calme, le ciel bleu, les enfants qui rient

font illusion. Je vous dis que je sens un feu de bois.

Je vois et entends la chair grésiller, chuinter les huiles et les graisses

qui allument des feux dans les rues.

Les grands immeubles oscillent et vacillent comme des vieillards

avant de s'écrouler dans une cascade de briques.

Les cris et gémissements n'en finissent plus.

Les villes de la plaine brûlent.

Londres. Berlin. Vienne. Varsovie. Moscou.

Nuit après nuit, elles flambent comme d'énormes fagots 
sur le fond d'un ciel menaçant.

Une affreuse odeur de gaz recouvre l'Europe entière.

Quand les villes se seront entièrement consumées

les cieux s'ouvriront

et de violentes pluies torrentielles tomberont pendant quarante jours

et quarante nuits.

Tout ce qui vit est submergé et noyé.

Je ne vois pas d'arche tanguer sur les flots.

\section{FOR MY BROTHER JESUS}

My father had terrible words for you

- whoreson, bastard, meshumad;

and my mother loosed Yiddish curses

on your name and the devil's spawn

on their way to church

that scraped the frosted horsebuns

from the wintry Montreal street

to fling clattering into our passageway

Did you ever hear an angered

Jewish woman curse? Never mind the words:

at the intonation alone, Jesus,

the rusted nails would drop out

from your pierced hand and feet

and scatter to the four ends of earth

Luckless man, at least

that much you were spared

In my family, you

were a mamzer, a yoshke pondrick

and main reason for affliction and pain.

Even now gentle father's lips;

my mother's never-ending singsong curses

still ring in my ears more loud

than the bells I heard each Sunday morning,

their clappers darkening the outside air

Priests and nuns

were black blots on the snow

- forbidden birds, crows

(1982 - A Wild Peculiar Joy: Selected Poems 1945-1982,

Toronto, McClelland \& Stewart, 1982)

\section{POUR MON FRÈRE JÉSUS}

Mon père avait des mots terribles pour toi

- fils de pute, bâtard, meshumad;

et ma mère lâchait une bordée d'injures en yiddish

sur ton nom et sur les rejetons du diable

qui sur le chemin de l'église

ramassaient le crottin de cheval gelé

dans la rue enneigée de Montréal

pour le jeter bruyamment dans notre entrée 
As-tu jamais entendu jurer une femme juive

en colère? Peu importent les mots :

à l'intonation seule, Jésus,

les clous rouillés tomberaient

de tes mains et pieds perçés

et se disperseraient aux quatre coins de la terre

Malheureux homme, au moins

cela t'a-t-il été épargné

Dans ma famille tu

étais un mamzer, un yoshke pondrick

et la raison première des calamités et des douleurs.

Même aujourd'hui les paroles de mon bon père;

l'interminable psalmodie des jurons de ma mère

résonnent encore dans mes oreilles plus fort

que les cloches que j'entendais le dimanche matin

leurs battants obscurcissant l'air dehors

Prêtres et nonnes

comme des taches noires sur la neige

- sinistres oiseaux, corbeaux

\section{Coda justificatrice d'une traduction impossible et nécessaire}

«Dans la compréhension commune, habituelle, je témoignais de quelque chose; comprendre désormais que "quelque chose" témoigne en moi et de moi. Le sujet n'est pas porteur du témoignage mais l'inverse. Le fait que je puisse et veuille témoigner atteste que je suis investi de parole et d'historicité; je ne suis pas dépositaire passif d'une postériorité, j'en témoigne en l'énonçant» (Alexis Nouss, «Témoigner», Spirale, no 168, p. 12).

«Pour connaître une chose ressentie, il faut d'abord qu'elle apparaisse devant vos yeux, subie par d'autres. Ce que l'on connaît pour l'avoir vécu auparavant ne devient réel qu'à ce moment-là. Sans qu'on puisse le nommer, cela repose dans l'être, puis c'est soudain présent comme une image, et ce qui arrive à d'autres se crée soudain en vous-même en tant que souvenir: alors c'est réel» (Elias Canetti, Histoire d'une vie. Le Flambeau dans l'oreille, traduit par Michel-François Demet, Paris, Albin Michel, 1982).

"Ainsi la teneur originelle d'une œuvre poétique, bref l'intensité de son rapport à l'origine, ne peut-elle se révéler qu'en trouvant asile dans le mouvement d'exode qu'entraîne sa traduction dans une langue qui pour l'accueillir doit connaître les douleurs de l'enfantement dans son propre élément » (Laurent Lamy, «La déshérence du clandestin», TTR, vol. 10, n 2, p. 101).

«Sans minimiser les résistances, la traduction fait apparaître que l'identité, au lieu de s'opposer à l'altérité, n'advient que par l'altérité. La relation d'opposition transformée en relation d'historicité, le métissage » (Henri Meschonnic, Politique du rythme, poétique du sujet, Lagrasse, Verdier, 1995, p. 449-450). 
154 MetA, XLV, 1, 2000

\section{NOTES}

1. Irving Layton (1982): «Le Carillon», Exile (York University), vol. 9, $\mathrm{n}^{\circ} 1$.

2. Irving Layton, ibid.

3. Elias Canetti (1982): Histoire d'une vie. Le Flambeau dans l'oreille, traduit par Michel-François Demet, Paris, Albin Michel.

4. Elias Canetti, ibid.

5. Irving Layton (1978): Aux victimes de l'Holocauste.

6. G. Bensoussan (1998): Auschwitz en héritage, Paris, Éditions Mille et une nuits.

7. Robert Marteau, Registre, Seyssel, Champ Vallon.

8. Irving Layton (1980): For Hans, maybe Klaus or Tadeusz.

9. Jean-Luc Godard (1998): Histoire(s) du cinéma - I, Paris, Gallimard-Gaumont, p. 93. 